\title{
GEOCHRONOLOGY OF THE HOLOCENE OF THE BELORUSSIAN POLESSIE
}

\author{
A. V. MATVEEV, E. A. KRUTOUS and V. P. ZERNITSKAYA
}

Institute of Geology, Geochemistry and Geophysics, Belorussian Academy of Sciences

7, Zodinskaja St., Minsk 220600 Belorussia

\begin{abstract}
We distinguished major stages of the last glaciation (Bølling, Older Dryas, Allerød, Younger Dryas) and the Holocene by radiocarbon dating and paleobotanical analyses. Our paleobotanical investigation of peatlands is well correlated with independent ${ }^{14} \mathrm{C}$ data. We establish that the Atlantic and Subboreal stages of the Holocene have three divisions, and that the Subatlantic has two.
\end{abstract}

\section{INTRODUCTION}

The Belorussian Polessie is a part of the Polessie Lowland, the central part of which is occupied by the Pripyat River valley (Fig. 1). This region has widespread flat unforested bogs, formed mainly during the Holocene. Peat constitutes up to $40 \%$ of the surface area in some geomorphological regions (Pidoplichko et al. 1972). In the early 1900s, several researchers described the peculiar geological structure of the Polessie, and studied the high frequency of flooding in the area. Systematic studies of peat bogs began in the 1920s, when the problem of extensive drainage reclamation arose. V.S. Dokturovsky and S. Kulchinsky considered the structure of peat deposits and the evolutionary history of Holocene bog lands. Later, Tjuremnov (1951), Makhnach and Tsapenko (1959), Makhnach (1971) and Pidoplichko $(1961,1975)$ studied stratigraphic and paleogeographic features. At present, the Belorussian University, the industrial society "Belorusgeologya" and the Belorussian Academy of Sciences are investigating these deposits.

\section{DATING OF POLESSIE PEAT DEPOSITS}

Paleobotanical studies in Polessie are difficult because of its location some distance from the boundary of the last glaciation; vegetation changes are not as clear in Polessie pollen diagrams as in those from northern regions. During the last glacial retreat, melting caused erosional gaps in the geologic record and sandy sediments favored accelerated development of pine in forest communities through the Holocene. Pollen analysis, geological surveys and geochronological studies indicate the presence of numerous lake basins in the south of Belorussia during the last glaciation and at the beginning of the Holocene. These water bodies originated in mostly shallow topographic depressions, and eventually filled and became peat bogs covering $\sim 700 \mathrm{~km}^{2}$. At these sites, sapropel, marl and silt with plant debris are at the bottom of the peat section. Lacustrine deposits are at least $3 \mathrm{~m}$ thick.

The oldest deposits found in sections of peat bogs in south Belorussia are related to the Bølling interval. According to pollen analysis, pine forests were widespread during this period, with simultaneous development of pine-birch forests and minor oak, Corylus. Enlargement of water bodies, development of floating bogs, and peat accumulation on lake perimeters began as early as the end of the Older Dryas and Allerød; these processes were possibly due to lake drainage. Climatic conditions were severe during deposition. The vegetation of the Belorussian Polessie was characterized by pine forests with birch, including Betula nana $\mathrm{L}$. and $B$. humilis $\mathrm{L}$., but most areas were open, forest-free landscapes. 


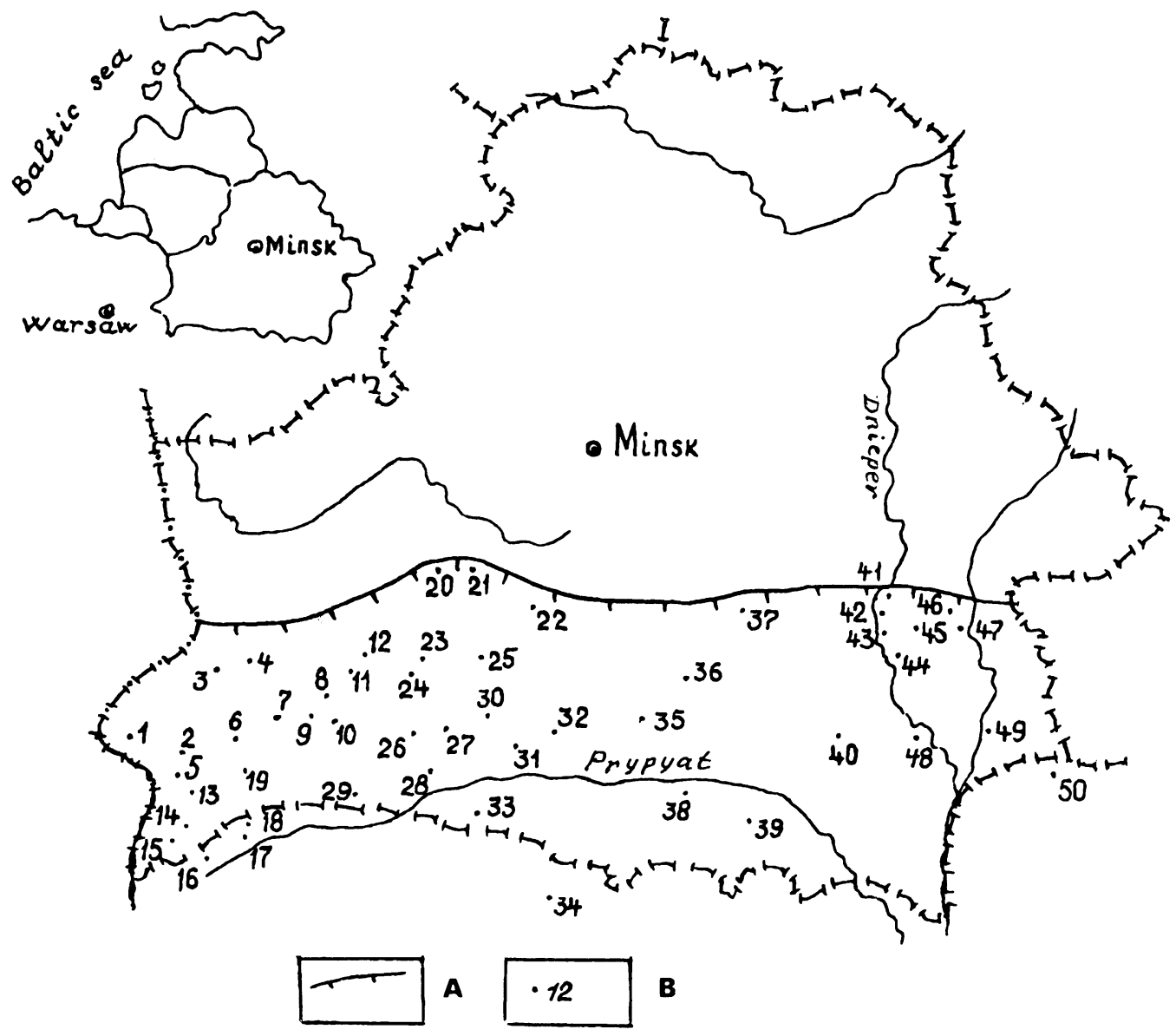

Fig. 1. Map of Holocene sections in the Belorussian Polessie: A. Boundary of the studied region; B. Number and name of the section: 1. Sychi; 2. Sekhnovichy; 3. Dikij Nikor; 4. Voschinichy; 5. Gusak; 6. Kobrin; 7. Temra; 8. Lake Chernoye; 9. Lake Sporovskoye; 10. Zditovo; 11. Yaglevichy; 12. Ljubischitsy; 13. Mysljachy; 14. Lake Oltush; 15. Lake Orekhovskoye; 16. Zabolotye; 17. Gornika; 18. Kortilisy; 19. Zaorye; 20. Lake Koldychevskoye; 21. Chernikhovo; 22. Novosolky; 23. Lake Vygonovskoye; 24. Lake Bobrovichskoye; 25. Gantsevichy; 26. Ivanisovka; 27. Pogost; 28. Pinsk; 29. Koleno; 30. Lake Beloye; 31. Luninets; 32. Goritsa; 33. Gorodnaya; 34. Yelno; 35. Lake Chervonoye; 36. Oressky; 37. Diloye; 38. Kandel-Yalovets; 39. Verkhy; 40. Vasilevichy; 41. Zborovo; 42. Luchin; 43. Zhlobin; 44. Nesoye Borok; 45. Belitskoye; 46. Gordok; 47. Sredniye Malynichy; 48. Tiraspol; 49. Karavishal; 50. Zaimischy.

During Allerød warming, vegetation consisted mainly of coniferous forests with birch, alder, minor oak, hornbeam and linden, with Corylus underbrush. Fir comprised up to $10-15 \%$ of conifer pollen types.

$\mathrm{A}{ }^{14} \mathrm{C}$ date of $1280 \pm 310 \mathrm{BP}$ (Vs-366) was obtained from the Chernikhovo section (Fig. 1) from a palynologically defined Allerød layer. This result makes the deposits almost $1000 \mathrm{yr}$ older than indicated by the standard Late-Glacial geochronological scale. This is probably due to hydrological peculiarities of the paleobasin regime and the presence of Neogene allochthonous deposits in underlying strata, as indicated by a high Neogene pollen content in the pollen spectra (Fig. 2). Punning (1987), Hakansson (1979) and Olsson (1979) discuss such errors. 


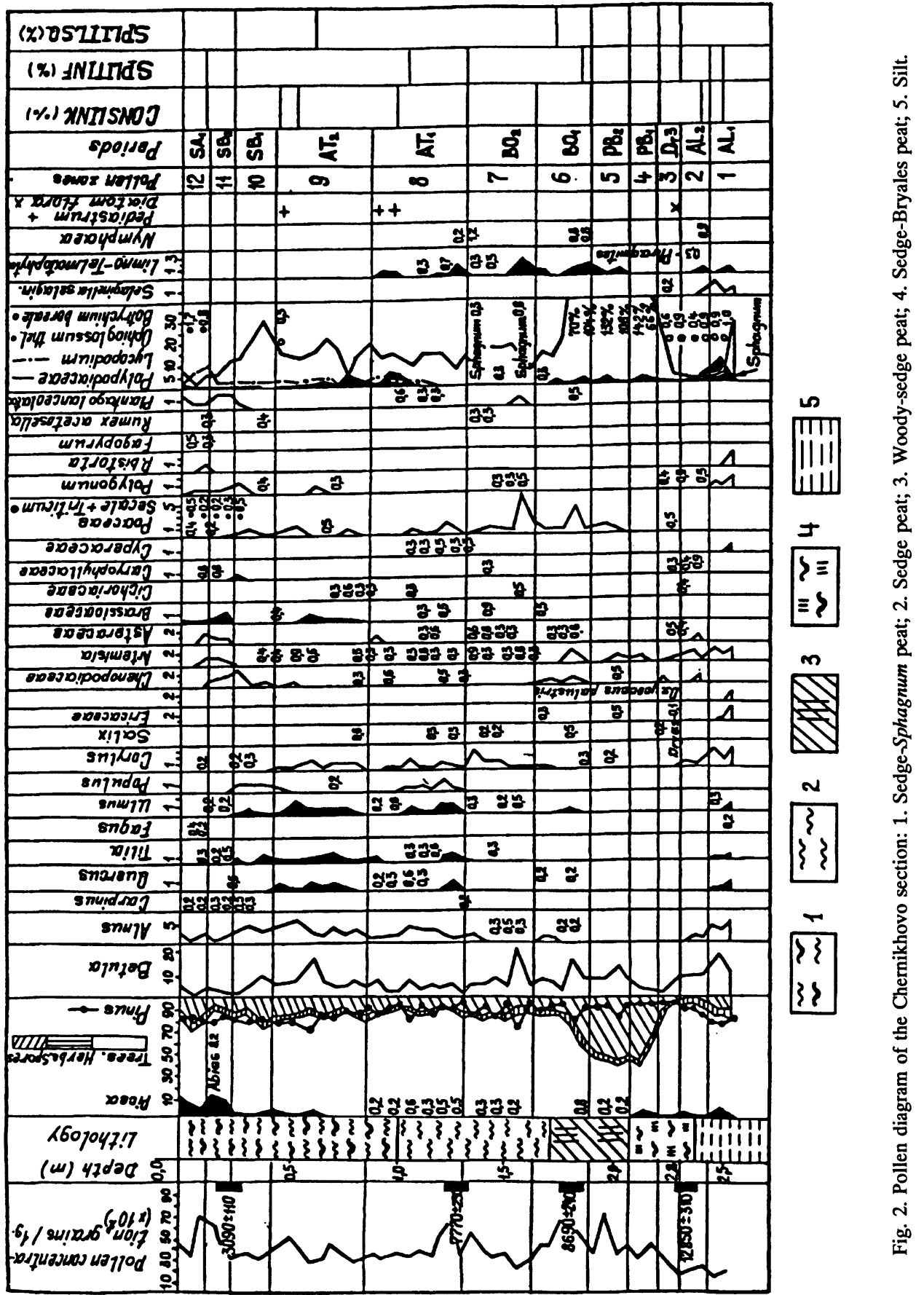


During the Younger Dryas, periglacial-type vegetation was widespread, along with decreasing temperature. Broad-leaved tree species disappeared. Pine-birch forests were located on uplands and sandy plains. Birch, including shrub forms of Betula nana $\mathrm{L}$. and B. humilis Schrank. dominated the tree species; vast areas were open. According to paleocarpological analysis, Younger-Dryas deposits included numerous megaspores of Selaginella selaginoïdes (L.) Link, seeds of Betula alba L., B. nana L., B. humilis Schrank., and among herbaceous plants, seeds of Chenopodium urbicum L., Potentilla anserina L. and Carex sp.

Early Holocene warming caused a succession of changes in vegetal cover. During the Preboreal, light birch-pine forests appeared with minor fir, Corylus, elm and alder. Eastward, broad-leaved species constituted $c a .1 \%$ of trees. Pine dominated in upland forests, reaching $90 \%$ in the west and $70-75 \%$ in the east; birch comprised $7-30 \%$ and $18-20 \%$, respectively. Birch increased to $46 \%$ in lowland forests. Geological, hydrological and climatic conditions affected the percentages of tree species in western and eastern forests. Only single grains of Selaginella selaginoides and Betula nana were found in peat bogs. Seed flora of lacustrine sediments included numerous chara shells, Potamogeton, with dominating Potamogeton rutilus Wolfg., which presently grow in the north of Belorussia and in the Vitebsk district, single grains of Najas marina L. and Caulinia minor (All.) Coss. \& Germ.

The age of the peat at the Boreal boundary of the Novosolky section (Fig. 1) was $9270 \pm 150 \mathrm{BP}$ (Tln-586). During the Boreal, the entire southern region of Belorussia was forested. Major forest species were pine and birch; fir appeared, and broad-leaved species (linden, oak, elm, hornbeam and alder) increased; hazel grew in the underbrush layer. Peat accumulated rapidly during this period. Palynological data show that grasses were dominated by aqua-bog and bog species. Flora included bog plants, such as Carex and Ranunculus, along with chara shells, Potamogeton and water lily. $\mathrm{A}{ }^{14} \mathrm{C}$ result for the Boreal obtained in the Novoselky section was $8600 \pm 70 \mathrm{BP}$ (Tln585 ), and for the Chernikhovo section, $8690 \pm 240$ BP (Vs-365).

The Atlantic was the warmest part of the Holocene. Climatic conditions favored the distribution of broad-leaved tree species and the expansion of diverse plant species. Vegetation varied distinctly between west and east, caused by differences in elevation and topography. Broad-leaved pine and black alder forests were evident on plains and in lowlands. Pollen analysis shows that the Atlantic included two, or in some sections (e.g., Verkhy) three subdivisions differing in climate and vegetation. In Early Atlantic time, coniferous and broad-leaved forests with pine, fir, birch, oak, elm and minor hornbeam were widespread in southern Belorussia. Shrubs included Corylus, alder and osier. Comparison of pollen diagrams within the region reveals that, in the east, pine constituted $51-62 \%$, birch, 3-7\%, alder, up to $56 \%$; in the west, pine increased to $90 \%$, birch, to $10 \%$, and alder decreased to $4 \%$.

The Middle Atlantic was characterized by the decrease of fir, alder and broad-leaved species in forest communities, which was caused by the colder climatic conditions compared to those of the Early Atlantic. Toward the end of the Atlantic, broad-leaved species increased again (broad-leaved species reached $7 \%$ in the east of the Belorussian Polessie and 10\% in the west). The Late Atlantic constitutes a thermal maximum, which, according to seed studies, shows the widest distribution of thermophilic vegetation, such as Najas marina L., Caulinia minor (All.) Coss. \& Germ., Nymphaea alba L., Salvinia natans (L.) All. and Stratiotes aloïdes $\mathrm{L} .{ }^{14} \mathrm{C}$ data confirm paleobotanical results. The following dates were obtained for Atlantic deposits: $7770 \pm 230$ BP (Vs-367) (Chernikhovo section); $7850 \pm 80 \mathrm{BP}$ (Tln-584), $7010 \pm 70 \mathrm{BP}$ (Tln-582) (Novosolky section), and $7020 \pm 70 \mathrm{BP}$ (Tln-588) (Zditovo section) (Fig. 1). 
A slight decrease in temperature and drying were observed for the Subboreal. Fir, oak, elm and other broad-leaved forest species declined. Climatic conditions were not stable during this period. Pollen data indicate three distinct stages for the Subboreal, with a warmer middle interval, when broad-leaved forest species increased slightly (Zditovo section). Some thermophilic species became dominant. Oak increased in the eastern Polessie during the second half of the Subboreal. Seed flora differed from the previous period; the total amount of plant remains (especially thermophilic) decreased. The following ${ }^{14} \mathrm{C}$ results were obtained for the Subboreal period: $4120 \pm 100 \mathrm{BP}$ (Vs425), $3190 \pm 85$ (Vs-426) (Verkhy section) and $3090 \pm 110$ BP (Vs-368) (Chernikhovo section) (Fig. 1).

With increased humidity during the Subatlantic, fir increased (up to $12 \%$ in the Chernikhovo section) and hornbeam was ubiquitous. The Subatlantic is divided into two parts, SA-1 and SA-2. During SA-1, pine decreased with increasing birch; broad-leaved species, including oak and hornbeam, increased. During SA-2, pine increased, but birch, alder and broad-leaved species decreased. It is difficult to illustrate the regularities of vegetation change during the Subatlantic, especially SA-2, as these deposits are more often affected by anthropogenic activity. Development in the Belorussian Polessie has left few natural bogs; many are plowed or used as fuel sources.

\section{REFERENCES}

Hakansson S. 1979 Radiocarbon activity in submerged plants from various South Swedish lakes. In Suess, H. E. and Berger, R., eds, Radiocarbon Dating. Proceedings of the 9th International ${ }^{14} \mathrm{C}$ Conference. Berkeley/Los Angeles, University of California Press: 433-443.

Makhnach, N. A. 1971 Stages of the vegetation evolution in Belorussia during the Anthropogen. In Science and Technology in Old Khozyaistve: $212 \mathrm{p}$.

Olsson I. U. 1979 A warning against radiocarbon dating of samples containing little carbon. Boreas 8(2): 203-207.

Pidoplichko, A. P. 1961 Peat deposits of the Belorussian SSR. In Science and Technology in Old Khozyaistve: $192 \mathrm{p}$.

1975 Lake deposits of the Belorussian SSR: Genesis, stratigraphy and some characteristics. In Sci- ence and Technology in Old Khozyaistve: 120 p.

Pidoplichko, A. P., Gorbutovich G. D., Kanoiko M. A. and Lopotko M. Z. 1972 Peat and sapropel deposits. Problemy Polessja. In Science and Technology in Old Khozyaistve: 292-313.

Punning, J.-M. 1987 Methods of dating Late Cenozoic deposits: Possibilities and restrictions. New Data Concerning Quaternary Geochronology. Moscow: 8-15.

Tjuremnov, S. N. 1951 Evolutionary history of peat lands of the BSSR during post-glacial time. Publications of the Belorussian Academy of Sciences 1: 88111.

Tsapenko, M. M. and Makhnach, N. A. 1959 Anthropogenic deposits of Belorussia. Publications of the Belorussian Academy of Sciences: 226 p. 